\title{
Complications after non-surgical management of proximal humeral fractures: a systematic review of terms and definitions
}

Stig Brorson ${ }^{1,2^{*}}$ (D) Nikola Alispahic ${ }^{3}$, Christian Bahrs ${ }^{4}$, Alexander Joeris ${ }^{5}$, Amir Steinitz $^{6}$ and Laurent Audigé ${ }^{7}$

\begin{abstract}
Background: A majority of proximal humeral fractures can be managed without surgery. Recent randomized clinical trials and meta-analyses even question the benefit of surgical treatment for displaced 3-, and 4-part fractures. However, evidence-based treatment recommendations, balancing benefits and harms, presuppose a common reporting of complications and adverse events, which at the moment is largely missing. Therefore we systematically reviewed the use of terms and definitions of complications after nonsurgical management of proximal humeral fractures.

Methods: We searched PubMed, EMBASE, Cochrane Library, Scopus and WorldCat (2010-2017) and included articles and book chapters containing complication terms or definitions. Two reviewers independently extracted and grouped terms and definitions according to a predefined scheme. Terms and definitions concerning nonsurgical management were tabulated, grouped and analyzed qualitatively.

Results: The initial search identified 1376 references from which 470 articles were selected for full-text retrieval. Data-extraction included first articles published in 2017, was then performed iteratively in batches of 20 articles, and terminated after retrieval of 91 articles when no additional definitions or terms was found. In addition, 12 book chapters were reviewed from an initial list of 100. No general definition of a complication was found. A total of 69 terms for complications after non-surgical management were identified from 19 articles. Sixty-seven terms regarded local events. The most commonly reported event terms regarded osteonecrosis, malunion, secondary displacement and rotator cuff problems. Seven individual terms were accompanied by some kind of definition. Most terms and definitions were based on radiographical assessments.
\end{abstract}

Conclusions: We found no consensus in the use of terms and definitions of complications after nonsurgical management of proximal humeral fractures. Multiple terms, some synonymous, some partly synonymous, some distinct, were used. Few complication terms were explicitly defined. Development and validation of an internationally consensus-based core event set for complications after proximal humeral fractures managed nonsurgically is needed.

Keywords: Proximal Humeral fractures, Non-surgical, Complications, Adverse events, Systematic review

* Correspondence: sbror@regionsjaelland.dk

'Department of Orthopaedic Surgery, Zealand University Hospital, Køge,

Denmark

${ }^{2}$ Department of Clinical Medicine, University of Copenhagen, Copenhagen,

Denmark

Full list of author information is available at the end of the article

(c) The Author(s). 2019 Open Access This article is distributed under the terms of the Creative Commons Attribution 4.0 International License (http://creativecommons.org/licenses/by/4.0/) which permits unrestricted use, distribution, and reproduction in any medium, provided you give appropriate credit to the original author(s) and the source, provide a link to the Creative Commons license, and indicate if changes were made. The Creative Commons Public Domain Dedication waiver (http://creativecommons.org/publicdomain/zero/1.0/) applies to the data made available in this article, unless otherwise stated. 


\section{Background}

Proximal humeral fractures (PHF) are common fractures and account for $4-6 \%$ of all fractures [1-3]. They are associated with osteoporosis and $78 \%$ of the fractures are seen in patients above the age of 65 [4]. Since 1970 it has been widely believed that $85 \%$ of all PHF were minimally displaced and could be managed non-surgically while the remaining 15\% were displaced and should be managed surgically [5]. However, more recent epidemiological studies have consistently reported much higher prevalences of displaced fractures ranging from 51 to $86 \%[3,6-8]$. The most commonly performed surgical procedures include internal fixation with locking plates or humeral nails or replacement of the humeral head with a hemiarthroplasty or a total reverse prosthesis. However, recent randomized clinical trials [9-12] and meta-analyses of randomized trials [13-18] or non-randomized trials $[19,20]$ have questioned the benefits of these procedures, even for displaced fractures. A call for more non-surgical treatments of PHF has emerged in the scientific literature [21-24].

Any evidence-based recommendation of a treatment modality, surgical or non-surgical, presupposes knowledge on benefits and harms. Guidelines for reporting of clinical effects with validated clinical outcome instruments are available and widely used. However, when it comes to reporting of complications and adverse events after management of PHF there is a paucity of standardized and validated terms and definitions. The majority of clinical studies on PHF deal with surgical management [25] and some complications like hardware failure and infection are obviously linked to surgery. However, complications following non-surgical management of PHF have not been systematically reviewed. Therefore, we aimed to systematically review the use of terms and definitions of complications after non-surgical management of PHF.

\section{Methods}

We conducted a systematic review of published peer-reviewed articles and book chapters according to the PRISMA (Preferred Reporting Items for Systematic Reviews and Meta-Analyses) guidelines [26].

\section{Search strategy}

A search was conducted (June 2017) in PubMed, EMBASE, Cochrane Library and Scopus covering the years 2010-2017. The search strategy for journal articles is found in Additional file 1. For book chapters we searched WorldCat (2016-2017) using the search terms (humer* fra?tur* OR shoulder fra?tu*). We included references in English, German and French language.

\section{Study selection and data-extraction}

After exclusion of duplicates, two reviewers (A.S. and N.A.) screened the initial reference list by title and abstract. A third author (L.A.) reviewed any ambiguous abstracts to reach consensus on the article's inclusion. Considering all included references we started full-text review and data extraction with the most recent references published in 2017 followed by consecutive series of 20 randomly selected references within previous years in reverse chronology. This process was terminated when all reviewers agreed that no additional relevant information was obtained. For all included references we documented bibliographical data and noted any general definition of 'complication' or 'adverse event' and any definition of individual complications or adverse events. We documented all individual complication terms reported and grouped them according to the relevant interventions. Terms related to non-surgical interventions were extracted for further analysis. The initial data-extraction was checked by a second reviewer and discrepancies were resolved by consensus. All data were managed and stored in a database using the data capture system REDCap [27] (Version 6.16.5, ( 2018 Vanderbilt University).

\section{Data synthesis}

Extracted event terms were organized according to predefined event groups and specifications adapted from Audigé et al. [28]. Event term definitions were tabulated.

\section{Results}

The initial search yielded 1376 references (Flow chart, Fig. 1). Based on titles and abstracts we excluded 906 references that did not comply with the inclusion criteria. Thus, 470 references remained for full-text retrieval. Data extraction was terminated in consensus within the review group when 91 articles and 12 book chapters had been retrieved in full text and no new terms or definitions was identified in the last group of references.

A total of 19 references (15 articles [13, 29-42] and 4 book chapters [24, 43-45]) reported terms and definitions of complications after non-operative management of PHF. The remaining references were excluded because they dealt with surgical management exclusively. From all the terms that were documented as being reported in the context of non-operative treatment, we identified the related papers, and then by checking back to these papers found out that only 19 papers were specifically focused on non-operative management.

After excluding spelling errors and clearly synonymous words 69 complication terms remained for further analysis (Table 1). They were grouped into 7 broad groups 


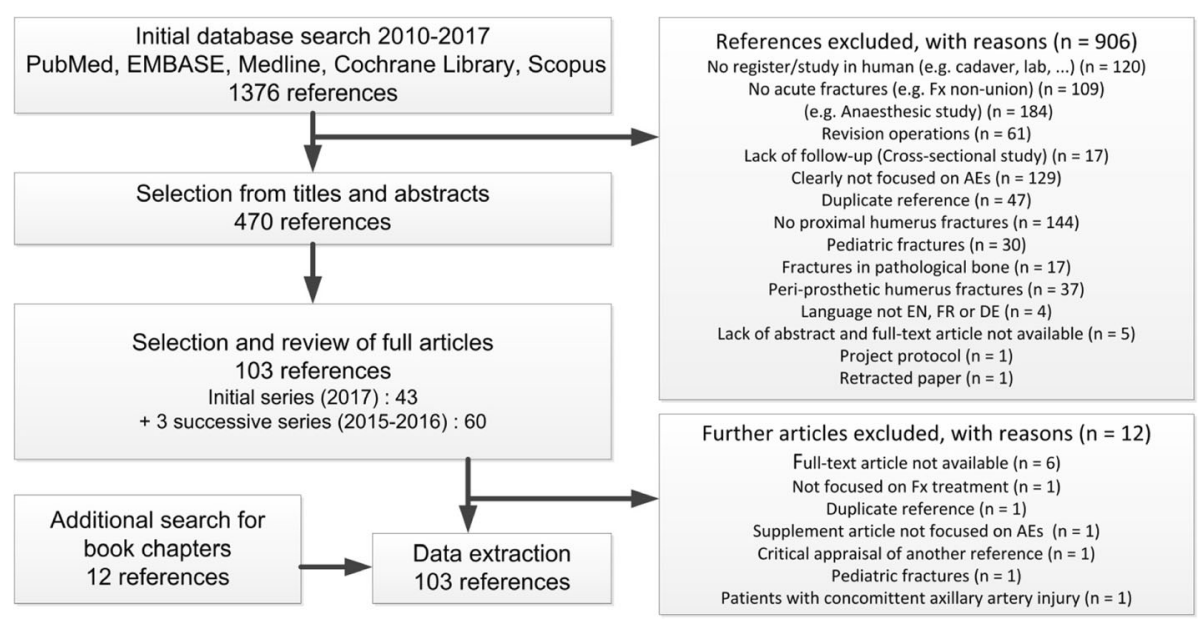

Fig. 1 Review flow diagram

and 11 subgroups. Seven complication terms were defined.

\section{Complication terms}

All 69 complication terms were initially divided into local and non-local events. Local events were further grouped into 'osteochondral,' 'instability', 'shoulder pain', 'neurological', 'soft tissue (superficial)', and 'soft tissue (deep)'.

The largest group (39 terms) was the 'osteochondral' group covering the subgroups 'arthritis', 'tuberosity migration/resorption, 'osteonecrosis', 'delayed union', 'malunion' and 'secondary fracture displacement'. All 39 event terms in this group were radiographically based.

The second largest group, 'soft tissue (deep)' (21 terms) covered 'impingement', 'capsular,' 'stiffness' and 'rotator cuff'. These event terms were defined clinically or by magnetic resonance imaging (MRI).

The remaining event terms were related to instability, pain, neurological injury, skin problems and the non-local events pneumonia and deep venous thrombosis.

\section{Definitions}

Among the full text searches we found 7 complication definitions. Six out of 7 definitions regarded radiographically defined events like malunion, nonunion, displacement and avascular necrosis (Table 2). Loss of power in arm was the only non-radiographically defined event term.

\section{Discussion}

We found no consensus in the use of terms and definitions of complications after non-surgical management of PHF. Only very few definitions of complications and adverse events were identified. Relatively few references on non-surgical management were identified compared to surgical interventions. This confirms the findings of Slobogean et al. [25] who conducted a scoping review of the literature on PHF and reported that less than 5\% of the body of literature dealt with non-surgical management compared to more than two thirds concerning surgical management. Despite this bias towards surgical literature we find it important to focus on complications after non-surgical management. A systematic reporting of complications and adverse events is needed for evidence-based suggestions and balanced decision-making [46].

\section{'Radiographical complications'}

Most terms and definitions of adverse events are based on assessments of radiographs. Assessments based on radiographs may favor surgical management as osteosynthesis and arthroplasty aim to restore the anatomy of the proximal humerus or to replace the damaged joint. To designate a certain radiographic pattern as a complication or an adverse event does not necessarily mirror the functional outcome and expectations as reported by the patient. Displaced fractures in adults can be expected to heal with some degree of malunion when treated non-surgically. In that sense, a malunion is not necessarily an adverse event from the patient's perspective. Even severe maluninon may be tolerated by patients with limited functional demands. More knowledge is needed to clarify the association between patient reported outcome and radiographically defined complications after non-surgical management.

Displacement, migration, malunion and nonunion are continuous variables brought into distinct categories often by poorly defined cut-off values. Three references proposed explicit definitions of 'secondary varus displacement' [13] 'tuberosity displacement' [39] and 'varus 
Table 1 Adverse event terms

\begin{tabular}{|c|c|c|}
\hline Event group & Event subgroup & Event term \\
\hline \multirow[t]{36}{*}{ Osteochondral } & & Heterotopic bone formation \\
\hline & & Humeral head resorption \\
\hline & Arthritis & Degenerative arthritis \\
\hline & & Osteoarthritis \\
\hline & & Post-traumatic arthritis \\
\hline & & Post traumatic osteoarthritis \\
\hline & $\begin{array}{l}\text { Tuberosity migration/ } \\
\text { resorption }\end{array}$ & $\begin{array}{l}\text { Superior migration of greater } \\
\text { tuberosity }\end{array}$ \\
\hline & & $\begin{array}{l}\text { Posterior migration of lesser } \\
\text { tuberosity }\end{array}$ \\
\hline & & $\begin{array}{l}\text { Medial displacement of the } \\
\text { greater tuberosity }\end{array}$ \\
\hline & & Displaced greater tuberosity \\
\hline & Osteonecrosis & Osteonecrosis \\
\hline & & $\begin{array}{l}\text { Osteonecrosis of the } \\
\text { humeral head }\end{array}$ \\
\hline & & $\begin{array}{l}\text { Necrosis of the humeral } \\
\text { head }\end{array}$ \\
\hline & & $\begin{array}{l}\text { Avascular necrosis of the } \\
\text { humeral head }\end{array}$ \\
\hline & & Avascular necrosis \\
\hline & & Head avascular necrosis \\
\hline & & Humeral head ischemia \\
\hline & & $\begin{array}{l}\text { Loss of perfusion of the } \\
\text { humeral head }\end{array}$ \\
\hline & Delayed union & Delayed union \\
\hline & & Prolonged delayed union \\
\hline & Malunion & Malunion \\
\hline & & Valgus malunion \\
\hline & & Varus malunion \\
\hline & & $\begin{array}{l}\text { Varus malunion in } \\
\text { anteversion }\end{array}$ \\
\hline & & $\begin{array}{l}\text { Varus malunion in } \\
\text { retroversion }\end{array}$ \\
\hline & & Greater tuberosity malunion \\
\hline & & Malunion of the tuberosities \\
\hline & Nonunion & Nonunion \\
\hline & & Fracture non-union \\
\hline & & Pseudoarthrosis \\
\hline & $\begin{array}{l}\text { Secondary fracture } \\
\text { displacement }\end{array}$ & Secondary displacement \\
\hline & & Fracture displacement \\
\hline & & Varus collapse \\
\hline & & Cephalic collapse \\
\hline & & $\begin{array}{l}\text { Complete displacement } \\
\text { of the humeral shaft }\end{array}$ \\
\hline & & $\begin{array}{l}\text { Malposition of lesser } \\
\text { tuberosity }\end{array}$ \\
\hline
\end{tabular}

Table 1 Adverse event terms (Continued)

\begin{tabular}{|c|c|c|}
\hline Event group & Event subgroup & Event term \\
\hline & & Malreduction ${ }^{a}$ \\
\hline & & Poor fracture reduction ${ }^{a}$ \\
\hline Instability & & $\begin{array}{l}\text { Recurrent shoulder } \\
\text { dislocation }\end{array}$ \\
\hline \multirow[t]{3}{*}{ Shoulder pain } & & Pain \\
\hline & & Persistent pain \\
\hline & & Shoulder pain \\
\hline \multirow[t]{3}{*}{ Neurological } & & $\begin{array}{l}\text { latrogenic neurovascular } \\
\text { injury }^{\mathrm{a}}\end{array}$ \\
\hline & & Axillary nerve lesions \\
\hline & & $\begin{array}{l}\text { Complex regional pain } \\
\text { syndrome }\end{array}$ \\
\hline $\begin{array}{l}\text { Soft tissue } \\
\text { (superficial) }\end{array}$ & & Skin irritation \\
\hline \multirow{21}{*}{$\begin{array}{l}\text { Soft tissue } \\
\text { (deep) }\end{array}$} & Impingement & Impingement \\
\hline & & $\begin{array}{l}\text { Impingement of the greater } \\
\text { tuberosity }\end{array}$ \\
\hline & & Subacromial impingement \\
\hline & & $\begin{array}{l}\text { Internal rotation } \\
\text { impingement }\end{array}$ \\
\hline & & Coracoidal impingement \\
\hline & & $\begin{array}{l}\text { Impingement of the greater } \\
\text { tuberosity on the acromion }\end{array}$ \\
\hline & Capsular & Capsular contracture \\
\hline & & Capsulitis \\
\hline & & Adhesive capsulitis \\
\hline & & $\begin{array}{l}\text { Secondary adhesive } \\
\text { capsulitis }\end{array}$ \\
\hline & & Frozen shoulder \\
\hline & Stiffness & Stiffness \\
\hline & & Shoulder stiffness \\
\hline & & Stiff shoulder \\
\hline & & Self-limiting stiffness \\
\hline & Rotator cuff & Rotator cuff tear \\
\hline & & Rotator cuff pain \\
\hline & & Rotator cuff weakness \\
\hline & & Rotator cuff deficiency \\
\hline & & Rotator cuff dysfunction \\
\hline & & Rotator cuff injury \\
\hline \multirow[t]{2}{*}{ Non-local } & & Pneumonia \\
\hline & & Deep Venous Thrombosis \\
\hline
\end{tabular}

${ }^{\mathrm{a} A f t e r}$ closed reduction

malunion' [41] based on measurements of degrees and millimeters on radiographs. The scientific and clinical validity of such definitions may be questioned and further studies may contribute to elucidate the clinical relevance of these commonly used complication terms. 
Table 2 Summary of definitions of adverse events

\begin{tabular}{lll}
\hline Author & Event term & Event definition \\
\hline Handoll (2015) [13] & Avascular necrosis (score 2-0) & $\begin{array}{l}\text { Score } 2=\text { no changes/1=changes to normal trabecular } \\
\text { organisation }<50 \% \text { of humeral head/0 }=>50 \% \text { of } \\
\text { humeral head or partial collapse }\end{array}$ \\
& Secondary varus displacement & $>10^{\circ}$ \\
Handoll (2015) [13] & Tuberosity displacement & $>5 \mathrm{~mm}$. \\
Kancherla (2017) [39] & Loss of power in arm (grade 0-5) & Medical Research Council Scale (grade 0-5) [47] \\
Fang (2017) [29] & Delayed union/non-union/prolonged delayed union & $\begin{array}{l}\text { Union between } 61 \text { and } 89 \text { days/when fractures had } \\
\text { not united by } 90 \text { days/union after } 90 \text { days }\end{array}$ \\
Papakonstantinou (2017) [41] & Narus malunion & Neck-shaft angle $\leq 110^{\circ}$ \\
Papakonstantinou (2017) [41] & Non-union (indirect definition) & Presence of callus uniting the main fragments \\
Papakonstantinou (2017) [41] & of fractures in 3 of the 4 bone cortices
\end{tabular}

The complication terms and definitions identified for non-surgical management can roughly be divided generically into three groups:

\section{Pathoanatomical entities}

'Humeral head necrosis' and 'capsulitis' are pathoanatomical diagnoses applied to radiological, clinical or intra-operative findings. Similarly, non-local terms like 'pneumonia' and 'DVT' are clinical and para-clinical (radiographs, ultrasound, blood tests) diagnoses rarely verified by pathologists.

\section{Pathophysiological entities}

'Loss of perfusion' leading to 'humeral head ischemia' and eventually 'avascular necrosis of the humeral head' are successive changes in a pathophysiological process. This process is quantified in the 3-stage definition of 'avascular necrosis' [13].

The process leading to 'non-union' or 'pseudoarthrosis' is captured in the 3-stage definition 'delayed union', non-union', or 'prolonged delayed union' [41].

\section{Biomechanical entities}

The terms related to rotator cuff problems are based on a biomechanical understanding of successive changes caused by muscular imbalance. The term 'rotator cuff' is usually followed by specifications like 'tear' and 'injury' (based on imaging), 'pain' (based on history), or 'dysfunction' and 'deficiency' (based on a functional understanding).

The terms related to 'impingement' are based on a biomechanical understanding of the process leading to pain and impairment. 'Internal rotation impingement' is clinically defined while 'impingement of the greater tuberosity on the acromion' illustrates a biomechanical understanding.

\section{Future aspects}

To obtain consensus on terms and definitions we plan to apply a Delphi consensus process based on the findings from the systematic review. An international group of shoulder surgeons will independently assess and comment on the proposed terms and definitions through a series of online surveys. A core event set will be developed and further validated. A similar approach has previously been applied to complications associated with arthroscopic rotator cuff tear repair [28].

\section{Conclusions}

Based on this systematic review we found no consensus on terms and definitions of complications and adverse events after non-surgical management of PHF. Most terms and definitions are based on radiographical assessments and the clinical relevance of terms and definitions from the patients' perspective remains to be demonstrated. We recommend steps towards the development of a core event set of complication terms based on consensus among shoulder and trauma specialists and with involvement of patient representatives in the validation process.

\section{Additional file}

Additional file 1: Search protocol for proximal humeral fractures in PubMed, Medline, Embase, Cochrane Library and Scopus. (PDF 649 kb)

\section{Abbreviations}

DVT: Deep venous thrombosis; MRI: Magnetic resonance imaging; PHF: Proximal humeral fracture

\section{Acknowledgements}

The authors acknowledge the support of Dr. Martina Gosteli, medical librarian at the University of Zurich, for implementing the final literature database search.

\section{Funding}

Laurent Audigé and Alexander Joeris worked as AOCID collaborators. The funding body (AO Trauma) had no role in the design of the study and collection, analysis, and interpretation of data or in writing the manuscript. 


\section{Availability of data and materials}

The final dataset will be available from the corresponding author.

\section{Authors' contributions}

SB: project plan, data extraction, data analysis, preparation of manuscript. NA: initial reference selection, data extraction, data analysis, review of manuscript. CB: project plan, data extraction, review of manuscript. AJ: project plan, review of manuscript. AS: initial reference selection, data extraction, data analysis, review of manuscript. LA: project leader, project coordination, project plan, database development and management, reference selection, data verification, statistical programming, data analysis, preparation of manuscript. All authors have read and approved the manuscript.

\section{Ethics approval and consent to participate} N/A

\section{Consent for publication}

N/A

\section{Competing interests}

The authors declare that they have no competing interests.

\section{Publisher's Note}

Springer Nature remains neutral with regard to jurisdictional claims in published maps and institutional affiliations.

\section{Author details}

'Department of Orthopaedic Surgery, Zealand University Hospital, Køge Denmark. ${ }^{2}$ Department of Clinical Medicine, University of Copenhagen, Copenhagen, Denmark. ${ }^{3}$ Department of Orthopaedic Surgery and Traumatology, University Hospital of Basel, Basel, Switzerland. ${ }^{4}$ Department of Traumatology and Reconstructive Surgery, Eberhard Karls University Tübingen, BG Trauma Center Tübingen, Tübingen, Germany. ${ }^{5} \mathrm{AO}$ Clinical Investigation and Documentation, Dübendorf, Switzerland. ${ }^{6}$ Crossklinik, Basel, Switzerland. ${ }^{7}$ Research and Development Department, Upper Extremities, Schulthess Clinic, Zurich, Institute for Clinical Epidemiology and Biostatistics, University Hospital of Basel, Basel, Switzerland.

Received: 10 January 2019 Accepted: 7 February 2019

Published online: 23 February 2019

\section{References}

1. Buhr AJ, Cooke AM. Fracture patterns. Lancet. 1959;273:531-6.

2. Knowelden J, Buhr AJ, Dunbar O. Incidence of fractures in persons over 35 years of age. A report to the M.R.C. Working party on fractures in the elderly. Br J Prev Soc Med. 1964;18:130-41.

3. Court-Brown CM, Garg A, McQueen MM. The epidemiology of proximal humeral fractures. Acta Orthop Scand. 2001;72:365-71.

4. Olsson C, Nordqvist A, Petersson CJ. Increased fragility in patients with fracture of the proximal humerus: a case control study. Bone. 2004;34:10727.

5. Neer CS. Displaced Proximal Humeral fractures. J Bone Jt Surg. 1970;52: 1077-89.

6. Roux A, Decroocq L, El Batti S, Bonnevialle N, Moineau G, Trojani C, et al. Epidemiology of proximal humerus fractures managed in a trauma center. Orthopaedics and Traumatology: Surgery and Research. 2012;98:715-9.

7. Tamai K, Ishige N, Kuroda S, Ohno W, Itoh H, Hashiguchi H, et al. Foursegment classification of proximal humeral fractures revisited: a multicenter study on 509 cases. J Shoulder Elb Surg. 2009;18:845-50.

8. Bahrs C, Stojicevic T, Blumenstock G, Brorson S, Badke A, Stöckle U, et al. Trends in epidemiology and patho-anatomical pattern of proximal humeral fractures. Int Orthop. 2014;38:1697-704.

9. Olerud P, Ahrengart L, Ponzer S, Saving J, Tidermark J. Hemiarthroplasty versus nonoperative treatment of displaced 4-part proximal humeral fractures in elderly patients: a randomized controlled trial. J Shoulder Elb Surg. 2011;20:1025-33.

10. Rangan A, Handoll H, Brealey S, Jefferson L, Keding A, Martin BC, et al. Surgical vs nonsurgical treatment of adults with displaced fractures of the proximal humerus the PROFHER randomized clinical trial. JAMA -J Am Med Assoc. 2015;313:1037-47
11. Boons HW, Goosen JH, Van Grinsven S, Van Susante JL, Van Loon CJ. Hemiarthroplasty for humeral four-part fractures for patients 65 years and older a randomized controlled trial. Clin Orthop Relat Res. 2012;470:3483-91.

12. Fjalestad T, Hole M, Jørgensen JJ, Strømsøe K, Kristiansen IS. Health and cost consequences of surgical versus conservative treatment for a comminuted proximal humeral fracture in elderly patients. Injury. 2010;41:599-605.

13. Handoll HH, Brorson S. Interventions for treating proximal humeral fractures in adults. Cochrane Database Syst Rev. 2015;(11):11, CD000434.

14. Xie L, Ding F, Zhao Z, Chen Y, Xing D. Operative versus non-operative treatment in complex proximal humeral fractures: a meta-analysis of randomized controlled trials. Springerplus. 2015;4:728.

15. Mao Z, Zhang L, Zhang L, Zeng X, Chen S, Liu D, et al. Operative versus nonoperative treatment in complex Proximal Humeral fractures. Orthopedics. 2014;37:e410-9.

16. Rabi S. Operative vs non-operative management of displaced proximal humeral fractures in the elderly: a systematic review and meta-analysis of randomized controlled trials. World J Orthop. 2015;6:838

17. Fu T, Xia C, Li Z. Wu H. Surgical versus conservative treatment for displaced proximal humeral fractures in elderly patients: a meta-analysis. Int J Clin Exp Med. 2014;7:4607-15.

18. Xie L, Ding F, Zhao Z, Chen Y, Xing D. Operative versus non-operative treatment in complex proximal humeral fractures: a meta-analysis of randomized controlled trials. Orthopedics. 2014;6:e543-51.

19. den HD, de HJ, Schep NW, Tuinebreijer WE. Primary shoulder arthroplasty versus conservative treatment for comminuted Proximal Humeral fractures: a systematic literature review. Open Orthop J. 2010;4:87-92.

20. Beks RB, Ochen Y, Frima H, Smeeing DPJ, van der Meijden O, Timmers TK, et al. Operative versus nonoperative treatment of proximal humeral fractures: a systematic review, meta-analysis, and comparison of observational studies and randomized controlled trials. J Shoulder Elb Surg. 2018;27:1526-34.

21. Maffulli N. We are operating too much. J Orthop Traumatol. 2017;18:289-92.

22. Aspenberg P. Why do we operate proximal humeral fractures? Acta Orthop. 2015:86:279

23. Jefferson L, Brealey S, Handoll H, Keding A, Kottam L, Sbizzera I, et al. Impac of the PROFHER trial findings on surgeons' clinical practice. Bone Jt Res. 2017;6:590-9.

24. Brorson S. Proximal Humeral Fractures. In: Court-Brown C, McQueen MM Swiontkowski MF, Ring D, Friedman SM, Duckworth A, editors. Musculoskeletal trauma in the elderly. Taylor \& Francis Group; 2017. p. 257-71.

25. Slobogean GP, Johal H, Lefaivre KA, Macintyre NJ, Sprague S, Scott T, et al. A scoping review of the proximal humerus fracture literature orthopedics and biomechanics. BMC Musculoskelet Disord. 2015;16.

26. Preferred Reporting Items for Systematic Reviews and Meta-Analyses (PRISMA), http://www.prisma-statement.org

27. Harris PA, Taylor R, Thielke R, Payne J, Gonzalez N, Conde JG. Research electronic data capture (REDCap)-a metadata-driven methodology and workflow process for providing translational research informatics support. J Biomed Inform. 2009:42:377-81.

28. Audigé L, Flury M, Müller AM, Durchholz H. Complications associated with arthroscopic rotator cuff tear repair: definition of a core event set by Delphi consensus process. J Shoulder Elb Surg. 2016;25:1907-17.

29. Fang C, Kwek EBK. Self-reducing proximal humerus fractures. J Orthop Surg (Hong Kong). 2017;25

30. Nikola C, Hrvoje K, Nenad M. Reverse shoulder arthroplasty in acute fractures provides better results than in revision procedures for fracture sequelae. Int Orthop. 2014;39:343-8.

31. Okike K, Lee OC, Makanji H, Morgan JH, Harris MB, Vrahas MS. An Original Study Comparison of Locked Plate Fixation and Nonoperative Management for Displaced Proximal Humerus Fractures in Elderly Patients; 2015.

32. Patel $\mathrm{S}$, Colaco HB, Elvey ME, Lee MH. Post-traumatic osteonecrosis of the proximal humerus. Injury. 2015:46:1878-84.

33. Schairer WW, Nwachukwu BU, Lyman S, Craig EV, Gulotta LV. Reverse shoulder arthroplasty versus hemiarthroplasty for treatment of proximal humerus fractures. J Shoulder Elb Surg. 2015;24:1560-6.

34. Sabharwal S, Patel NK, Griffiths D, Athanasiou T, Gupte CM, Reilly P. Trials based on specific fracture configuration and surgical procedures likely to be more relevant for decision making in the management of fractures of the proximal humerus: findings of a meta-analysis. Bone Joint Res. 2016;5:470.

35. Sethi PM, Macken CJ. Management of Greater Tuberosity Fractures. Tech Shoulder Elb Surg. 2016;17:102-9. 
36. Sharaby MMF. Results of biological restoration of varus impacted proximal humeral fracture and stabilization with locked plate and calcar screws. Curr Orthop Pract. 2016;27:524-9.

37. Biazzo A, Cardile C, Brunelli L, Ragni P, Clementi D. Early results for treatment of two- and three-part fractures of the proximal humerus using contours PHP (proximal humeral plate). Acta Biomed. 2017;88:65.

38. Hageman MGJS, Meijer D, A. Stufkens S, Ring D, N. Doornberg J, Ph. Steller E. Proximal Humeral Fractures: nonoperative versus operative treatment. Arch Trauma Res 2016;6.

39. Kancherla VK, Singh A, Anakwenze OA. Management of Acute Proximal Humeral Fractures. J Am Acad Orthop Surg. 2017;25:42-52.

40. Lowry V, Bureau NJ, Desmeules F, Roy JS, Rouleau DM. Acute proximal humeral fractures in adults. J Hand Ther. 2017:30:158-66.

41. Papakonstantinou MK, Hart MJ, Farrugia R, Gosling C, Kamali Moaveni A, van Bavel $D$, et al. Prevalence of non-union and delayed union in proximal humeral fractures. ANZ J Surg. 2017;87:55-9.

42. Park YK, Kim SH, Oh JH. Intermediate-term outcome of hemiarthroplasty for comminuted proximal humerus fractures. J Shoulder Elb Surg. 2017;26:85-91.

43. Brunner UH. Kapitel 18 - Kopferhaltende Therapie der proximalen Humerusfraktur. In: Habermeyer P, Lichtenberg S, Loew M, Magosch P, Martetschläger F, Tauber M, editors. Schulterchirurgie (Fünfte Ausgabe). Fünfte Aus. Munich: Urban: Fischer; 2017. p. 483-534.

44. Esenyel EZ. The shoulder. In: The shoulder. Cham: springer international publishing, Cham; 2017. p. 101-13.

45. Bohsali K, ABMW. Fractures of the Proximal Humerus. In: Rockwood and Matsen's the shoulder. Fifth edit. Philadelphia, PA: Elsevier; 2017. p. 183-242.

46. Jacxsens M, Walz T, Durchholz H, Müller AM, Flury M, Schwyzer HK, Audigé L. Towards standardised definitions of shoulder arthroplasty complications: a systematic review of terms and definitions. Arch Orthop Trauma Surg. 2017;:137:347-55

47. John J. Grading of muscle power: comparison of MRC and analogue scales by physiotherapists. Medical Research Council Int J Rehabil Res Int Zeitschrift fur Rehabil Rev Int Rech Readapt. 1984;7:173-81.

Ready to submit your research? Choose BMC and benefit from:

- fast, convenient online submission

- thorough peer review by experienced researchers in your field

- rapid publication on acceptance

- support for research data, including large and complex data types

- gold Open Access which fosters wider collaboration and increased citations

- maximum visibility for your research: over $100 \mathrm{M}$ website views per year

At $\mathrm{BMC}$, research is always in progress.

Learn more biomedcentral.com/submissions 